\title{
OPTIMIZATION OF COMMUNES' SERVICES BY NETWORK COOPERATION WITH PRIVATE COMPANIES
}

\author{
MARCIN FLIEGER
}

General Tadeusz Kościuszko Military University of Land Forces in Wrocław, Department of Management, POLAND e-mail: marcin.flieger@awl.edu.pl

RECEIVED
ACCEPTED
JEL
CLASSIFICATION

KEYWORDS

ABSTRACT

\begin{abstract}
22 June 2017
15 December 2017

$\mathrm{H} 11, \mathrm{H} 41, \mathrm{~L} 32$

network relations, network organization, commune, private company, public services

The main purpose of the article is to determine possibilities and conditions of optimizing the process of providing services by communes by initiating and developing network cooperation with private companies operating in the region. At the beginning the author described the stages of the process of achieving network maturity in network cooperation. Next, the identified stages have been related to possible forms of network relations between communes and companies. As a consequence, the practical aspect of this network cooperation potential has been shown. Finally, the author answered the question to what degree the cooperation between communes and private companies operating in the region shows typical features of a network organization.
\end{abstract}

\section{Introduction}

Modern models of providing public services require flexibility and innovative approach. Communes, being the key unit of local public administration, must possess the ability to adjust to changing needs of their clients. Consequently, local authorities ought to limit exploitation of a supervisor function in favor of initiating partnership 
cooperation with various organizations operating in a region, including private companies. In this way they may optimize the process of providing services by taking advantage of a synergy effect and transfer of knowledge.

In this context the concept of a network cooperation between communes and local private companies seems a considerably attractive way of creating mutual relations. The network consists of knots (organizations) and relations between them, thanks to which the added value is created. The net becomes a very specific sort of cooperation based on horizontal dependences (Mitręga, 2010; Łobos, 2000; Newman et al., 2004). Hierarchical structure is not created (Flieger, 2016), since relations do not base on subordination. Moreover, each partner joins the network freely, in the process of searching for mutual benefits (Zimniewicz, Piekarczyk, 2010). Built relations allow the exchange (flow) of knowledge, skills and material resources (Downes, 2005).

The analysis and research results presented in the paper are a part of a scientific project realized by the author (Optyka procesowa oraz sieciowa w zarządzaniu instytucjami administracji publicznej, project financed by Ministry of Science and Higher Education, 77/WZA/46/DzS). The following research methods have been used: analysis of documents and law acts regarding functioning of local government institutions and collaboration with private organizations, study of literature concerning the characteristics of network relations (inter-organizational network), expert interviews with representatives of both communes and private organizations. Analyzed organizations operate in Great Poland and Lower Silesia voivodships. Such a methodology allows complex verification of possibilities of communes' involvement (initiation and development) in network collaboration.

\section{Process of achieving network relations maturity}

In order to realize tasks within a network, partners must understand mutual expectations and capabilities. After a preliminary verification of information, first joint initiatives are taken up. They are supposed to check in practice possibilities of cooperation. As a result, partners make further decisions which are to strengthen the bonds. Thus, creating optimal network structure constitutes a process which includes getting through some stages leading to network maturity (Baker, 1993).

The initial stage is the moment potential partners become aware of possibilities of realizing some ventures within network. It is especially difficult in case of communes, since their structure is hierarchical, not flexible, public servants must obey formal norms and regulations. Such an idea of the way an organization operates is substantially different from the concept of network cooperation, in which flexibility and partnership (flat structures) based on trust are crucial. Such a perspective requires a totally different attitude to the way an organization ought to operate. Of course resigning from hierarchical and formal functioning of communes is not possible. However, it is vital to realize that they do not have to follow this pattern completely. There is a possibility to realize tasks also through getting involved in network relations, including private companies operating in a region. Forms of such a cooperation may be very different, adjusted to needs and expectation of partners.

The second stage of achieving network maturity begins the moment potential partners initiate first relations, organize first meetings at which they have a chance to get to know one another and, as a consequence, assess whether there exist fields of potential cooperation, if it is possible to define common goals, priorities and strategies. At this stage contacts are informal and basically are limited to exchange of information.

If the process of getting to know one another leads to conclusion that there exists a platform for cooperation, the third stage appears. Basically, it means that partners declare that they are willing to either create or join network. This moment is crucial, since an initial informal network comes to life. 
The next, fourth stage of network development begins when organizations realize first common ventures. They do not generate high risk, often are limited to planning and coordinating initiatives which are supposed to increase synergy and cohesion. Still the very idea of such relations is to signal good will and building trust to one another. Partners make an attempt to define fields of possible future cooperation which will be beneficial for all.

The utter, most advanced stage of maturity in network relations is formal partnership. This level will be achieved only on condition that the experience from earlier cooperation have brought benefits and all partners trust one another. Network relations become confirmed by a formal agreement, in which fields of cooperation and responsibilities of all parties are stated. Such a formalization often constitutes a beginning of strategic partnership which allows achieving common, long-term objectives (Baker, 1993). Depicted process of achieving network maturity can be presented in a following synthetic way:

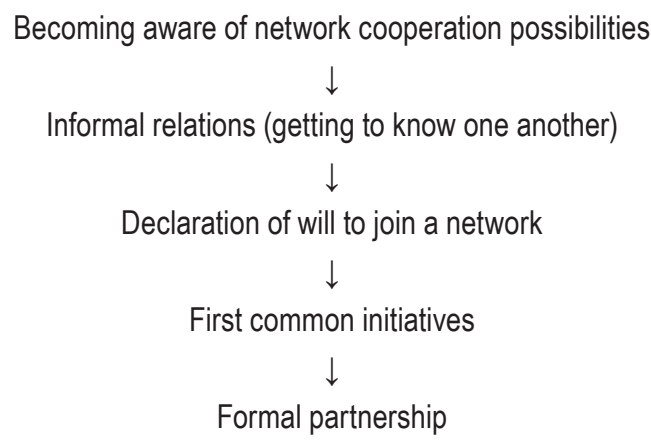

The abovementioned analysis of the process may be also depicted from a slightly different perspective of evaluation of cooperation forms (levels). The first level is characterized by defensive approach, separation, even conflicts. In a cooperation between communes and private sector organizations the source of a conflict might be e.g. fiscal policy of local administration. However, constant conflicts or competing may not be justified from a point of view of social and economic development of a region. Becoming conscious of this fact constitutes a key moment in the process of development of network relations. Joining forces and resources may bring considerably more benefits. Partners create unique added value, beneficial for all members of the network, by taking advantage of the synergy effect.

At the beginning such a cooperation is limited to coordination, bonds are rather loose, often informal. Realized ventures are low-risky, they allow better understanding of needs and mutual benefits. The relation changes with time, bonds become more tight and initiatives more complex and risky. As a result, optimal level of partnership is achieved. Depicted dependences can be shown in a following way:

Competing (conflict) $>$ coordinating > cooperating.

\section{Stages of network cooperation with private companies}

At the very beginning of the analysis of possible forms of network cooperation between communes and private companies it is crucial to make a fundamental distinction. There are two major fields of relations between the two parties. The first one concerns creating conditions for development of entrepreneurship (supporting business activity 
in a region). Such an activity of local authorities bases on supervisor-subordinate relations - a commune acts as a public institution which has a right to make and impose some decisions which have an impact on a private sector. In this case the relations have an indirect character. Therefore, from a perspective of creating network relations the second field is definitely more important. It focuses on initiating direct, partnership relations which private companies in order to realize specific tasks or projects. However, achieving coherent, partnership cooperation requires time. It constitutes a process which consists of a few general stages:

1. Informing - cooperation begins with exchange of information (in both directions). There are not any legal regulations which would state very clearly in what way the informing ought be realized, thus, it is up to both parties what channels and principles of communication they choose, depending on local needs and conditions. A platform for information exchange might be a dedicated web page or a unit in a public office. At this stage relations are still mostly informal and are supposed to get to know one another better, understand other party's objectives and expectations.

2. Consulting - it is a considerably more advanced form of cooperation. Consultation does not mean only allowing access to information regarding some projects, plans, legal acts, but also being open to express and share opinions and being ready to implement changes. At this stage informal relations become limited in favor of taking up first formal ventures. All parties create a base for joint coordination of realized tasks.

Example. Authorities of Skawina commune (major, his deputy and the president of city council) organize systematic meetings with local entrepreneurs. They allow presenting a vision of economic development and priorities in entrepreneurship support. Lately the commune has consulted development of Business Activity Zones (Strefy Aktywności Gospodarczej), new grounds for investments, revitalization of a technical and road infrastructure within a former Aluminum-works, opening of Investor Centre (Centrum Obsługi Inwestora) and adjusting an education system to the needs of a local labor market (www.gminaskawina. pl, access: 3.01.2017).

3. Forum of cooperation - it constitutes a valuable initiative which allows formalizing and systematizing rules of cooperation. Local companies become involved in solving local social and economic problems. What is especially important, a forum is a place where representatives of three sectors (private, public and non-governmental) may meet and discuss possible forms of further cooperation. In this way a network with various organizations (knots) and relations between them are created. It ought to base on strategic documents and sectors' programs implemented by public administration. Institutional adjustment of a local public office, in which a unit coordinating cooperation with a private sector is created, constitutes a key element of the formalization. At the same time the analysis of what a commune does in the field of supporting companies and investors is carried out.

4. Joint projects - it constitutes optimal maturity in network cooperation. All parties are equal partners, they join a network with the awareness of common objectives and mutual benefits. There are various possible forms of such a cooperation, depending on a social and economic character of a region and specific needs of all partners. However, at this point it seems adequate to mention two forms which allow strengthening network relations. Firstly, it is recommended that the network consists representatives of all sectors operating in a region, both public, private and other, especially non-governmental. Transfer of knowledge between organizations which have different experience and objectives allows realization of complex projects, taking advantage of a synergy effect and a potential of innovative solutions. The second 
form is a public-private partnership, whose main objective is to realize tasks and provide services, which are traditionally provided by a public sector, together with a partner from a private sector. The cooperation bases on an assumption that each party can realize assigned tasks more professionally and efficient than the other one. In this way partners complement one another, concentrating on activities within a project which they can do the best. Thanks to sharing tasks, responsibility and risk, a public-private partnership achieves economically optimal way of creating infrastructure and providing public services. At the same time each party gains benefits which are adequate to engagement.

Example. Major of Gostyń and one of local companies collaborate in the field of founding a so-called electric energy purchasing group. It constitutes a virtual client who buys energy for numerous partners. Joining a lot of local organizations is going to strengthen their position as a buyer, which means bigger possibilities for negotiating more beneficial conditions (www.gostyn.pl, access: 13.01.2017).

\section{Network coopepation features}

It is vital to be aware that the very fact of initiating cooperation between communes and private companies does not mean that at the same time it initiates creation of network relations. There is a need of taking up thoughtout measures in order to build and develop such a cooperation. However, in case of cooperation between the two parties in question, some typical features of network relations are quite natural, other require working on. Thus, at this point the question arises: to what degree cooperation between communes and private companies shows features of a network? In this context the features ought to be divided into three groups:

A. Network cooperation features are natural for analyzed relations - they include:

- free choice regarding joining and leaving the network - both parties are able to function and achieve their goals separately, they do not depend on one another. Access and leaving the net depend only on the analysis whether being in the network is beneficial or not,

- long-term cooperation - local authorities take advantage of instruments for supporting entrepreneurship and their perspective is long-term. Their priority is stable, systematic development of a region. Therefore, planning and realizing strategic cooperation with companies operating in a region is very natural,

- limiting competition in favor of cooperation - objectives of local public administration and private companies are not in conflict, it is natural that both parties initiate cooperation in order to increase efficiency, they complement one another,

- legal and organizational autonomy.

B. Network cooperation features start to appear as the cooperation reaches more advanced stages of network relations maturity:

- awareness of common objectives - basic goals of both parties are not convergent, that is why starting cooperation requires identifying common fields. However, it is plausible only if the bonds between potential partners become more tight and when they know well and trust one another,

- open communication system - as a result partners develop a negotiating form of coordinating actions - decisions are made together by all participants of the network. However, close, direct contacts are well-developed only when partners realize projects, such a dialog does not exist on earlier stages of the process of achieving network cooperation maturity, 
- access to partners' resources (synergy effect) - absolutely key resource is knowledge, which leads to innovative solutions. Transfer of knowledge appears at the most advanced stages (forum of cooperation, joint projects) - then partners learn from one another in the process of planning and realizing initiatives,

- trust - it is absolutely natural that to start trusting partners, they must have time to get to know one another. Therefore, the level of trust naturally depends on how advanced and tight the cooperation is.

C. Network cooperation features do not appear naturally:

- flexibility - at the beginning it must be clearly stated that theoretically this feature could be exploited freely - partners can change configuration of the network, optimally adjusting it to the needs of a particular project or a task. However, in practice this extremely valuable potential of a flexible adjustment to changing requirements and conditions is not used. Often cooperation bases on routine and repeating the same schemes. If partners do not carry out analysis of changes in the environment, new needs, chances and threats, they continue cooperation with the same organizations, they are not open for consultations, which considerably limits possibilities of reconfiguration of the network by access of new organizations,

- relations based on a process orientation - a turbulent nature of the environment requires building up natural ability to cope with challenges (Perechuda, 2000). That is why effective cooperation within a network ought to be based on process relations. Partners in a net can build relations basing on processes which are linked with one another. Such an approach strengthens horizontal, flat structures. Consequently, the network becomes more flexible and it is easier to adjust to changes (Bitkowska, 2009). However, although theoretically there are not any obstacles to base cooperation on a process structure (all partners can identify processes and manage them in order to optimize flow of resources), such an orientation is very rarely seen. Public offices (communes) have implemented a functional structure and exploit it when they build relations with other organizations (Nowak, 2006). Such an atomization makes it more difficult to coordinate operations between particular elements of the chain which creates the process of providing services (Flieger, 2012).

\section{Conclusions}

The concept of network cooperation may constitute a vital element of creating a modern model of providing public services (Jones et al., 1997; Head, 2008; O'Leary et al., 2010; Hooghe, Marks, 2001; Lynn, 2006). The process of achieving network maturity can be related to possible forms of cooperation between communes and private companies. Thus, the potential to create such network relations is considerable.

However, in order to exploit the possibilities of such a cooperation optimally, both parties need to take up active, well thought-out measures, including: initiating direct relations, developing partnership approach (limiting a supervisor's perspective), focusing on creating teams to realize common projects, changing configuration of the net to adjust to needs of clients (flexibility), considering the network in the context of a process orientation.

\section{References}

Baker, H.R. (1993). Building multi-community rural development partnership. In: R.C. Rounds (ed.), The structure, theory and practice of partnership in rural development (pp. 37-42). ARRG working papers series, no 5.

Bitkowska, A. (2009). Zarządzanie procesami biznesowymi w przedsiębiorstwie. Warszawa: Vizja Press \& IT. 
Downes, S. (2005). Semantic networks and social networks. The Learning Organization, 5, 411-415.

Flieger, M. (2016). Optymalizacja funkcjonowania instytucji administracji publicznej poprzez kooperację w sieci. Prace Naukowe Uniwersytetu Ekonomicznego we Wrocławiu, 421, 124-125.

Flieger, M. (2012). Zarządzanie procesowe w urzędach gmin. Model adaptacji kryteriów dojrzałości procesowej. Poznań: Wydawnictwo Naukowe UAM.

Grudzewski, W., Hejduk, I. (2004). Metody projektowania systemów zarządzania. Warszawa: Difin.

Head, B.W. (2008). Assessing network-based collaborations: effectiveness for whom? Public Management Review, 6 (10).

Hooghe, L., Marks, G. (2001). Multi-Level Governance and European Integration. London-New York-Boulder-Oxford: Rowman \& Littlefield Publishers.

Jones, C., Hesterly, W.S., Borgatti, S.P. (1997). A general theory of network governance: exchange conditions and social mechanisms. Academy of Management Journal, 4 (22), 912-920.

Lynn, L. (2006). New Public Management. New York: Routledge.

Łobos, K. (2000). Organizacja sieciowa. In: K. Perechuda (ed.), Zarządzanie przedsiębiorstwem przyszłości, koncepcje, modele, metody (pp. 98-103). Warszawa: Placet.

Mitręga, M. (2010). Zdolność sieciowa jako czynnik przewagi konkurencyjnej na rynku przedsiębiorstw. Katowice: Wydawnictwo Akademii Ekonomicznej im. Karola Adamieckiego.

Newman, J., Barnes, M., Sullivan, H., Knops, A. (2004). Public Participation and Collaborative Governance. Journal of Social Policy, 2.

Nowak, J.F. (2006). Modernizacja lokalnej administracji publicznej a rozwój lokalny. Poznań: Wydawnictwo Akademii Ekonomicznej w Poznaniu.

O'Leary, R., Slyke, D., Kim, S. (2010). The Future of Public Administration around the World: The Minnowbrook Perspective. Washington DC: Georgetown University Press.

Perechuda, K. (2000). Zarządzanie przedsiębiorstwem przyszłości, koncepcje, modele, metody. Warszawa: Placet.

www.gminaskawina.pl/index.php?option=16\&action=news_show\&news_id=11485 (3.01.2017).

www.gostyn.pl/SPOTKANIE_BURMISTRZA_Z_PRZEDSIEBIORCAMI_WSPOLPRACA_SPRZYJA_OSZCZEDNOSCIOM.htmI (13.01.2017).

Zimniewicz, K., Piekarczyk, A. (2010). Myślenie sieciowe w teorii i praktyce. Warszawa: Polskie Wydawnictwo Ekonomiczne, 12-24.

Cite this article aS:" Flieger, M. (2018). Optimization of communes' services by network cooperation with private companies. European Journal of Service Management, 2 (26), 79-85. DOI: 10.18276/ejsm.2018.26-10. 